\title{
THE CONISTON LIMESTONE SERIES.
}

Sir,-The Geologists Association visited the exposures of the volcanic rocks on the flanks of Roman Fell under my guidance, on the occasion of the Long Excursion to Cumberland in 1889, when they had an opportunity of examining the sections which it was the chief object of my paper on the Coniston Limestone series to describe. Other field geologists have at different times examined the same facts with me. The sections are not very easily found, and the relation of the various rocks to each other is certainly not very clear at first sight. But after repeated examinations of the Ordovician rocks of the whole of the area enclosed by the Pennine Faults it becomes evident that there are three well-marked horizons on which volcanic rocks occur. 'The highest of these is intimately associated with the base of the Coniston Limestone. The lowest consists of a series of tuffs of subaqueous origin, which are clearly interstratified with argillites resembling the Skiddaw Slates. These are the rocks of the Milburn Series, and are the submarine equivalents of the lower half of the Borrowdale volcanic series. The third includes the very pecnliar set of volcanic rocks which I have described as the Helton Moor volcanic series. These are quite different in litbological character from either of the other two, and as they cannot be newer than the first, nor older than the second, they must be of age intermediate between the two. All three types occur side by side on Helton Moor, as I have pointed out already on several occasions. It is in association with these that the shales of Lycum Sike occur. We have the best possible anthority for the occurrence in these beds of Lycum Sike of Trematis corona, which occur also in the shales belonging to the Coniston Limestone Series. Trematis corona is here, therefore, not available as a characteristic fossil, for the beds of Lycum Sike are separated by a considerable, if unknown, thickness of other rocks from the true Coniston Limestone Series " This latter overlies the rocks of Dufton and Knock Pikes, while the beds of Lyoum Sike lie at an unknown distance below.

Much more is involved in this question than a mere error of delineation, which no one who has attempted to map the complicated area in question could well avoid, here or there.

Unless I am very greatly mistaken it is the middle and the upper group of these volcanic rocks which occur at the northern end of the exposure near Melmerby, and it is the same two groups which form the volcanic groups on the north-east side of the Lake District. And, furthermore, I strongly suspect that there is a considerable unconformity between the two higher, or Bala, volcanic groups, and the Arenig and older rocks upon which they lie in Cumberland.

I have little doubt that the Ordovician tuffs of the Craven area also correspond to those of Helton Moor and Dufton; but whether the Ingleton Green Slate series lies unconformably below these, or

1 I regret very much that I did not write to Prof. Lapworth regarding what I understood him to say about the two horizons of Trematis corona at Girvan. I did not like to trouble an exceptionally busy man upon a matter that I thought he had already stated quite clearly. 'The error is mine. 
whether it represents the materials of the Milburn series mingled with detrital matter from the seaward margin of the Borrowdale volcanoes will probably long remain a matter of opinion.

In conclusion I may state that I should be glad to conduct a party of field geologists over the areas here referred to if the excursion can be arranged for the summer months. If Mr. Marr should care to be of the party, so much the better.

Edinbukgh Museum of Science and Art, $10 t h$ October, 1892 .

\section{J. G. GOODCHILD.}

\section{SHAPES OF SAND GRAINS.}

Sir,--It is interesting to find that my friend Mr. Reade admits the rounded sands in the Glacial deposits at Moel-y-'Tryfaen "may be treated as erratics."

This view has been held by many glacialists of the anti-submergence school for years. In a paper read before the Liverpool Geological Society in December last, I stated that under the microscope the glacial sands found under the cliffe bounding the Mersey were almost undistinguishable from those on the shore.

But this fact gives no support to the belief that marine conditions obtained during the deposition of those sands. It does not follow that the sands have been rounded by marine action at all.

It is particularly unfortunate that Mr. Reade should have cited the sands "which he has been living on and working in as an engineer for the last twenty-five years" as examples of sea-worn grains.

Not only is the shore skirted by sand dunes whose bases are washed by the tide, but the grains themselves have most probably been derived from the Triassic and Permian rocks which form the solid geology of the district.

The remarkable roundness of grain which characterizes many beds in these formations is well known.

Not less striking than the roundness is the uniformity in size of the grains in some beds. Some agent has been at work which is capable of sifting.

Through the kindness of various friends I have received specimens of sands from many parts of the Desert of Sahara. In one case I had examples from different depths at the same place. The underlying grains are small in size, fairly angular, and contain a large proportion of ferruginons grains. The upper layer is composed of larger grains, extremely well rounded and very uniform in size. In wind-borne material we should expect a sifting due to the varying resistances offered to the wind by the sand particles.

"Desert sands," according to Mr. Reade, "are of course out of the question in glacial geology;" but in the present case it is possible that "desert sands" of a former period may not be "out of the question" and the roundness of grain may have little importance in Glacial Geology.

Cniversity Coliege, Liverpool, J. Lomas.

October 13 th, 1892. 